\title{
45. SYNTHESIS OF THE LEG 39 BIOSTRATIGRAPHY (CENTRAL AND SOUTH ATLANTIC)
}

\author{
Katharina Perch-Nielsen, Department of Geology, Swiss Federal Institute of Technology, Zürich, Switzerland
}

\section{INTRODUCTION}

During Leg 39 of the Deep Sea Drilling Project, Sites 353 and 354 were drilled in the Vema Fracture Zone and on the Ceará Rise in the western central Atlantic. Sites 355 and 358 , in the Brazil Basin and Argentine Basin, respectively, and Sites 356 and 357 on the São Paulo Plateau and the Rio Grande Rise, lie in the western part of the South Atlantic. Site 359, on the western part of the Walvis Ridge, is in the eastern part of the South Atlantic (Figure 1).

Part 5 of this volume contains reports concerned with the biostratigraphy, paleontology, and paleobiogeography of material collected during Leg 39.

The three major microfossil groups usually used for biostratigraphy onboard ship-planktonic foraminifers, calcareous nannofossils, and radiolarians-were studied by Berggren, Boersma, Bukry, Dinkelman, Franz, Haq, Lohmann, Perch-Nielsen, and PremoliSilva. Diatoms from Sites 354, 356, and 358 were

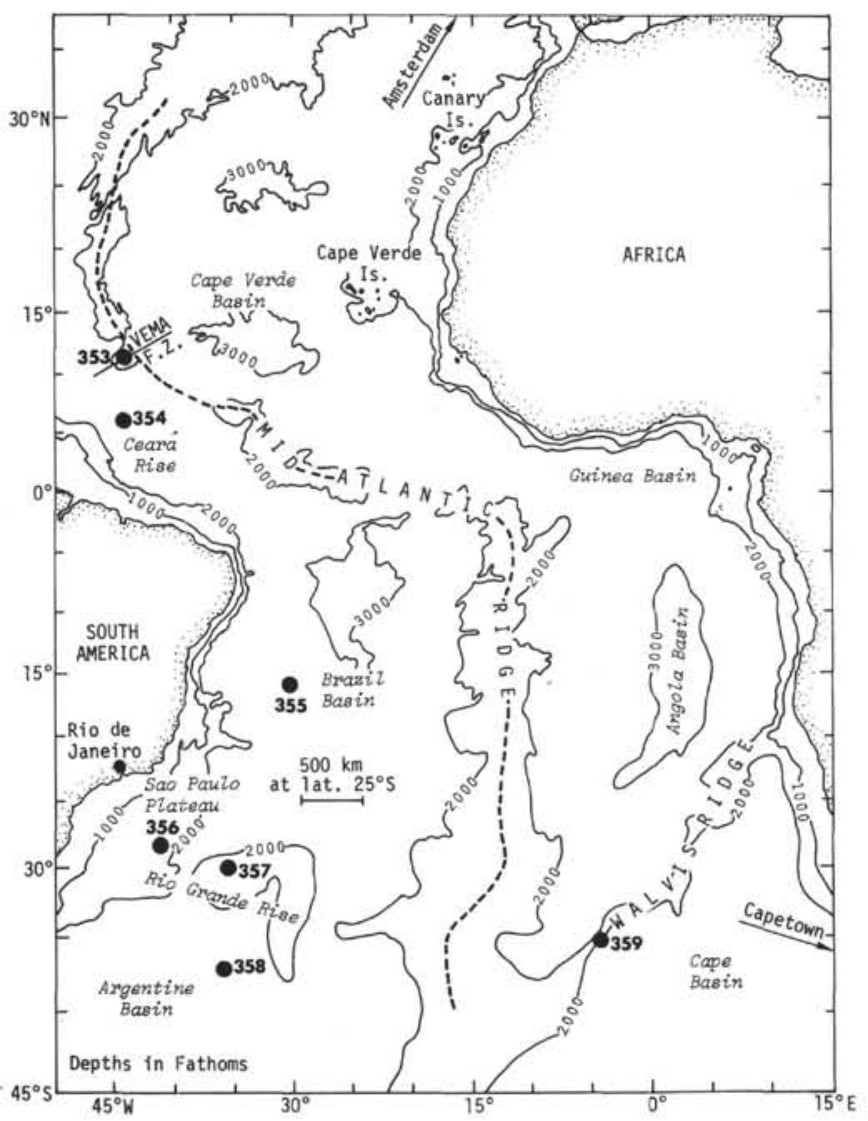

Figure 1. Leg 39 drill sites. studied by Fenner; palynomorphs from Sites 355, 356, and 358 by Ioannides and Colin; ostracodes from Sites 356 and 357 by Benson; silicoflagellates and other siliceous microfossils from Sites 354, 356, and 358 by Bukry and by Perch-Nielsen; benthic foraminifers from the Cretaceous by Sliter and from the Eocene to lower Miocene by Boersma. Thiede and Dinkelman report on the occurrence of Inoceramus, and Boersma and Shackleton have constructed detailed ${ }^{18} \mathrm{O}$ and ${ }^{13} \mathrm{C}$ records for the Tertiary at Site 357.

Tables 1 through 7 show the distribution, frequency, and preservation of the observed faunal and floral groups and the biostratigraphic ages based on them at each site, for each core.

In Tables 8 through 12, the distribution of Cretaceous, Paleocene, Eocene, Oligocene, and Neogene sediments at all sites is shown, together with the foraminifer, calcareous nannofossil, and radiolarian zones. The relative positions of zonal boundaries of the foraminifers and the calcareous nannofossils reveal some differences from hole to hole and differences with the correlations suggested by Berggren (1972), van Hinte (1976), and others.

\section{OCCURRENCE OF FOSSIL GROUPS}

Tables 1 through 7, which show occurrences of the various fossil groups, are mainly compilations of information available from the "Core Description Forms." Data for planktonic foraminifers, calcareous nannofossils, radiolarians, and silicoflagellates were taken from the "Fossil Character" column. For diatoms, sponge spicules, and fish debris, the information is from the lithological description and M. Dinkelman. Data on palynomorphs were extracted from Ioannides and Colin (this volume). The number of ostracodes found in a 20-cc sample at Sites 356 and 357 was taken from Benson (this volume). The occurrence of Inoceramus was also taken from the lithologic description; details of distribution can be found in Thiede and Dinkelman (this volume). Data for benthic foraminifers were supplied by A. Boersma.

Calcareous nannofossils and planktonic foraminifers usually occur with comparable frequencies and in comparable states of preservation in most Tertiary cores. In the Upper Cretaceous cores, however, planktonic foraminifers are missing while coccoliths are present and common, although poorly preserved, in the Campanian to lower Maestrichtian of Site 355, in some upper Santonian and Campanian samples at Site 357, and in Maestrichtian and Paleocene samples at Site 358. This can be explained by assuming that during these times the sites lay below the CCD of planktonic 
TABLE 1

Distribution, Frequency, and Age of Investigated Fossils at Site 353

\begin{tabular}{|c|c|c|c|c|c|c|c|c|}
\hline $\begin{array}{l}\text { Site } 353 \\
\text { Depth } \\
\text { (m) }\end{array}$ & Core & $\begin{array}{l}\text { Foran } \\
\text { Plank- } \\
\text { tonic }\end{array}$ & Benthic & $\begin{array}{l}\text { Calcareous } \\
\text { Nannofossils }\end{array}$ & Radiolaria & Diatoms & $\begin{array}{l}\text { Sponge } \\
\text { Spicules }\end{array}$ & Age \\
\hline $118.5-128.0$ & 2 & FM & VRP & $\mathrm{CM}$ & - & + & + & \\
\hline 261.0-270.5 & 3 & $\mathrm{CM}$ & FM & $\mathrm{CM}$ & - & & & $\begin{array}{c}\text { Late } \\
\text { Pleistocene }\end{array}$ \\
\hline $0.0-181-0$ & $1 \mathrm{~A}$ & AP & FP & $\mathrm{AM}$ & - & + & + & \\
\hline \multicolumn{9}{|c|}{ Key for tables $1-7:$} \\
\hline Frequency: & \multicolumn{8}{|c|}{ Preservation: } \\
\hline$A=$ abundant & \multicolumn{2}{|c|}{$\mathrm{G}=$ good } & \multirow{2}{*}{\multicolumn{2}{|c|}{ - absent }} & & & & \\
\hline $\mathrm{C}=$ common & \multicolumn{2}{|c|}{$\mathrm{M}=$ moderate } & \multirow{2}{*}{\multicolumn{2}{|c|}{+ present }} & & & & \\
\hline$F=$ few & \multirow{2}{*}{\multicolumn{4}{|c|}{ Key for tables $1-7$}} & & & & \\
\hline $\mathbf{R}=$ rare & & & & & & & & \\
\hline
\end{tabular}

TABLE 2

Distribution, Frequency, and Age of Investigated Fossils at Site 354

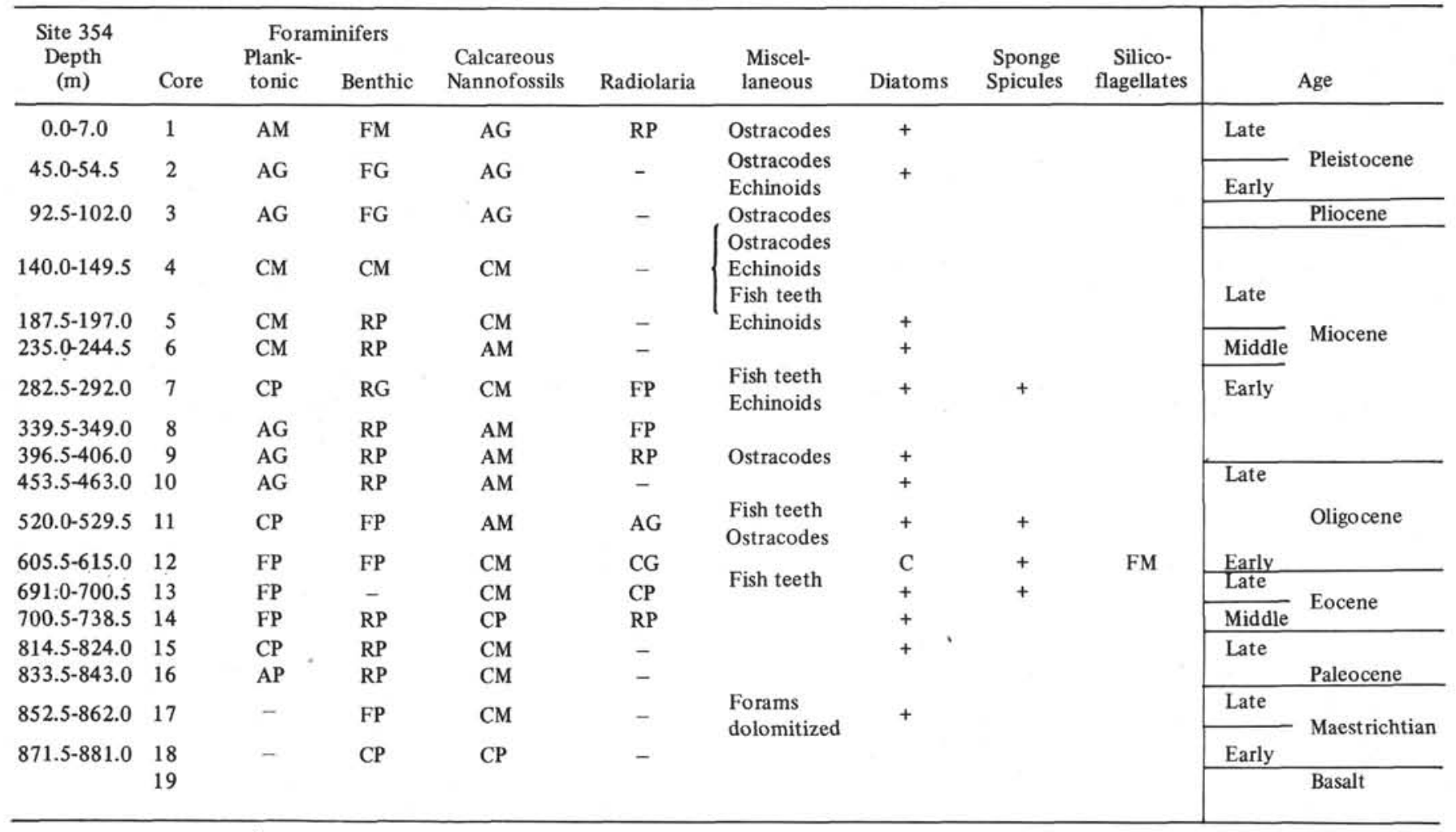

foraminifers but above the CCD of the coccoliths. Although this explanation is satisfactory for the basinal Sites 355 and 358, it would require a rise in these CCD's during late Santonian to late Campanian time in the vicinity of the Rio Grande Rise (Site 357), but not in the vicinity of the São Paulo Plateau (Site 356), where planktonic foraminifers are still present, though partially dissolved, and not at DSDP Site 21 , also on Rio Grande Rise (Maxwell et al., 1970), where the Campanian faunas and floras are well preserved. Since this seems unlikely, Premoli-Silva and Boersma (this volume) suggest that locally reducing conditions, rather than changes in the $C C D$, caused the intense dissolution of planktonic foraminifers at the nonbasinal sites.

Radiolarians occur mainly in the Eocene through lower Miocene of Site 354, the Eocene and lower
Miocene of Site 355, the upper Albian and Paleocene, Eocene and lower Miocene of Site 356, the middle Eocene and upper Oligocene through lower Miocene of Site 357, the Oligocene through Pleistocene of Site 358, and the upper Eocene of Site 359. Preservation is usually rather poor, but it is good in the lower Oligocene of Site 354, the middle Eocene of Site 356, and the upper Oligocene/Miocene to upper Miocene of Site 358 , where diatoms and silicoflagellates are also preserved. Sponge spicules are present in most samples containing radiolarians.

Fish debris, mainly teeth, occurs in varying amounts throughout the section recovered at Site 358 , and is especially common in Cores 14 through 18 of Site 355 . Palynomorphs were investigated only from short intervals at Sites 355,356 , and 358 , in which calcareous microfossils were rare or lacking (Sites 355 and 358), 
TABLE 3

Distribution, Frequency, and Age of Investigated Fossils at Site 355

\begin{tabular}{|c|c|c|c|c|c|c|c|c|c|c|}
\hline $\begin{array}{l}\text { Site } 355 \\
\text { Depth } \\
\text { (m) }\end{array}$ & Core & $\begin{array}{l}\text { Fora } \\
\text { Plank- } \\
\text { tonic }\end{array}$ & Benthic & $\begin{array}{l}\text { Calcareous } \\
\text { Nannofossils }\end{array}$ & Radiolaria & Diatoms & $\begin{array}{c}\text { Sponge } \\
\text { Spicules }\end{array}$ & $\begin{array}{l}\text { Palyno- } \\
\text { morphs }\end{array}$ & $\begin{array}{l}\text { Fish } \\
\text { Debris }\end{array}$ & Age \\
\hline $53.0-62.5$ & 1 & RP & VRVP & RP & - & & + & & + & Plio-Pleistocene \\
\hline $110.0-119.5$ & 2 & $\mathrm{CM}^{*}$ & FP & $\mathrm{CM}^{*}$ & - & + & + & & + & Late \\
\hline $167.0-176.5$ & 3 & $\mathrm{CP}^{*}$ & $\mathrm{CM}$ & $\mathrm{CM}^{*}$ & RP & + & + & & + & Early \\
\hline $214.5-224.0$ & 4 & - & - & - & $\mathrm{AM}$ & & & & & Middle \\
\hline $243.0-252.5$ & 5 & - & - & - & $\mathrm{CP}$ & & $\mathrm{F}$ & & & - - - Eocene \\
\hline $262.0-271.5$ & 6 & - & _ & - & $\mathrm{CP}$ & & & & + & \\
\hline $281.0-290.5$ & 7 & - & - & - & $\mathrm{CP}$ & & & & & Early \\
\hline $300.0-309.5$ & 8 & - & - & - & $\mathrm{CP}$ & + & & & & \\
\hline $319.0-328.5$ & 9 & - & - & - & $\mathrm{CP}$ & + & & & & \\
\hline $338.0-347.5$ & 10 & - & - & - & $\mathrm{CP}$ & & & & & \\
\hline $347.5-357.0$ & 11 & - & - & - & $\mathrm{CP}$ & & $\mathrm{R}$ & & & \\
\hline $357.0-366.5$ & 12 & - & - & - & FP & & $\mathrm{R}$ & & $\mathrm{R}$ & \\
\hline $366.5-376.0$ & 13 & - & - & - & $\mathrm{FP}$ & & $\mathrm{R}$ & & $\mathrm{F}$ & \\
\hline $376.0-385.5$ & 14 & - & - & - & FP & & $\mathrm{R}$ & & $\mathrm{F}$ & \\
\hline $385.5-395.0$ & 15 & - & - & - & $\mathrm{CP}$ & & & + & + & \\
\hline $395.0-404.5$ & 16 & - & - & - & - & & & - & $\mathrm{F}$ & $?$ \\
\hline $404.5-414.0$ & 17 & - & _- & $\mathrm{CP}$ & - & & & $(+)$ & & E. Maestrichtian \\
\hline $414.0-423.5$ & 18 & - & - & $\mathrm{CP}$ & - & & & & & to \\
\hline $423.5-433.0$ & 19 & - & - & $\mathrm{CP}$ & - & & & & & L. Campanian \\
\hline $433.0-442.5$ & 20 & - & - & $\mathrm{CP}$ & - & & & & & \\
\hline $442.5-452.0$ & 21 & - & - & $\mathrm{CP}$ & - & & & & & E. Camp. \\
\hline $452.0-461.5$ & 22 & - & - & RP & - & & & & & Basalt \\
\hline
\end{tabular}

*turbidites

and from the Site 356 Upper Cretaceous layers rich in organic matter. In the latter samples, and at Site 355 , no precise age was indicated by the palynomorphs. Upper Eocene to upper Oligocene assemblages were found at Site 358 (Ioannides and Colin, this volume).

\section{BIOSTRATIGRAPHY}

The distribution of Cretaceous through Pleistocene sediments at all sites and the occurrences of foraminifer, coccolith, and radiolarian zones are shown in Tables 8 through 12. Martini (1971), Berggren (1972), van Hinte (1976), and others have suggested correlations between foraminifer, coccolith, and radiolarian zonations. In the Leg 39 sequences, the relative positions of these zonal boundaries change in some instances and are the same in others. This is not unusual; Bukry et al. (1973) found that variations in the offset relations of foraminifer-coccolith-radiolarian zone boundaries occur even in single Deep Sea Drilling legs, where several significant variables in zone identification can be held relatively constant. The main reason for the discrepancies must be sought in the uncertainties in identifying taxa, especially poorly preserved forms, in the detection of reworking, where zonal boundaries are based on last occurrences of taxa, and in dissolution and ecological factors, since some sites compared are at different depths, separated by a barrier, or at opposite parts of a basin.

\section{Cretaceous}

The distribution of Cretaceous sediments at Sites 354 through 358 is shown in Table 8, where the foraminifer and coccolith zones are also given.

\section{Contact with "Basement"}

Oceanic basement was reached at two sites, 354 and 355. The planktonic foraminifers in the Upper Cretaceous at Site 354 have been dissolved; no radiolarians were found. The coccoliths allow recognition of the Maestrichtian Arkhangelskiella cymbiformis, Lithraphidites quadratus, and Nephrolithus frequens zones. The basement may thus be assumed to be of early Maestrichtian or older age.

Site 355 in the Brazil Basin was drilled to date the interval between magnetic anomalies 33 and 34 . The only calcareous fossils present in the whole Cretaceous sequence-including the lowermost sediments recovered in Core 21, which contained the sediment/basalt contact-were common but poorly preserved coccoliths and rare abyssal benthic foraminifers. The occurrence of Tetralithus aculeus, also at the bottom of the sediments in Core 21, suggests that this core is lower Campanian. In sediment particles found attached to the basalt in Core 22, an assemblage lacking both $T$. aculeus and Marthasterites furcatus was found and it is thus still of early Campanian age.

At Site 358 in the Argentine Basin, the interval between anomalies 32 and 33 should have been dated, but because of bad weather, the site had to be abandoned before we could reach basement. The oldest sediments recovered in the core catcher of Core 16 contain a coccolith assemblage of the Tetralithus trifidus Zone, of latest Campanian to earliest Maestrichtian age. The planktonic foraminifers, absent in Core 15 and the rest of Core 16, include Globotruncana tricarinata, G. arca, G. coronata and Rugoglobigerina rugosa in the core catcher of Core 16. This assemblage includes only a very few specimens, 
TABLE 4

Distribution, Frequency, and Age of Investigated Fossils at Site 356. Number of Ostracodes in a 20-cc Sample

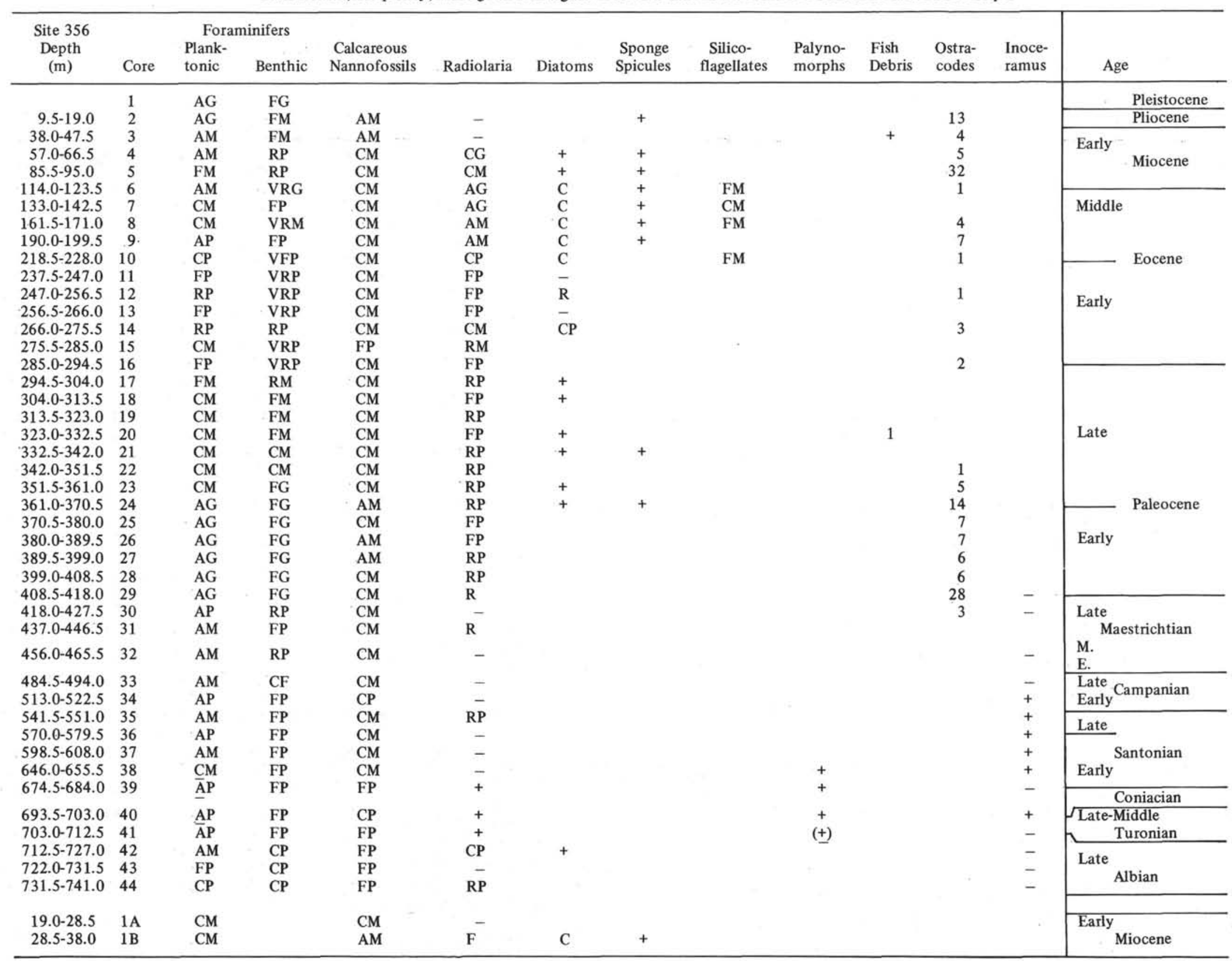


TABLE 5

Distribution, Frequency, and Age of Investigated Fossils at Site 357. Number of Ostracodes in a 20-cc Sample

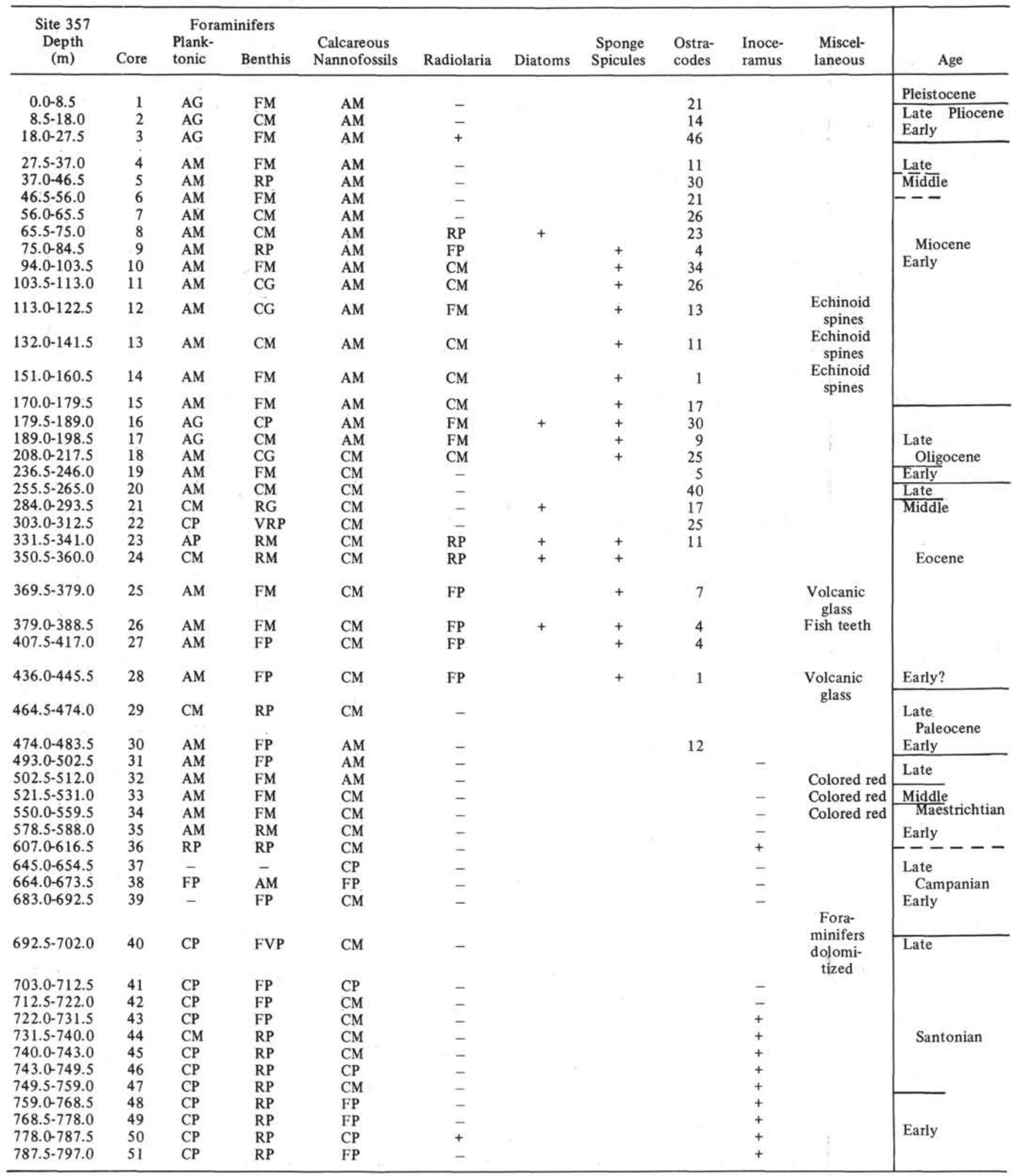

and the entire smaller fraction of planktonic foraminifers is missing. The assemblage was assigned to the lower Maestrichtian G. tricarinata Zone, thus making probable a late Campanian age for the 
TABLE 6

Distribution, Frequency, and Age of Investigated Fossils at Site 358

\begin{tabular}{|c|c|c|c|c|c|c|c|c|c|c|c|}
\hline $\begin{array}{l}\text { Site } 358 \\
\text { Depth } \\
\text { (m) }\end{array}$ & Core & $\begin{array}{l}\text { Fora } \\
\text { Plank- } \\
\text { tonic }\end{array}$ & Benthic & $\begin{array}{l}\text { Calcareous } \\
\text { Nannofossils }\end{array}$ & Radiolaria & Diatoms & $\begin{array}{l}\text { Sponge } \\
\text { Spicules }\end{array}$ & $\begin{array}{c}\text { Silico- } \\
\text { flagellates }\end{array}$ & $\begin{array}{l}\text { Palyno- } \\
\text { morphs }\end{array}$ & $\begin{array}{l}\text { Fish } \\
\text { Debris }\end{array}$ & Age \\
\hline \multirow{2}{*}{$47.5-57.0$} & \multirow{2}{*}{1} & \multirow{2}{*}{-} & \multirow{2}{*}{-} & \multirow{2}{*}{-} & \multirow{2}{*}{$\mathrm{FM}$} & \multirow{2}{*}{$\mathrm{C}$} & \multirow{2}{*}{$\mathrm{R}$} & \multirow{2}{*}{ RM } & \multirow[b]{6}{*}{+} & \multirow{7}{*}{$\mathrm{R}$} & Late Pleistocene \\
\hline & & & & & & & & & & & Early Pliocene \\
\hline $123.5-133.0$ & 2 & - & - & - & CG & C & + & RM & & & Late Miocene \\
\hline 199.5-209.0 & 3 & - & - & - & FP & - & $\mathbf{R}$ & - & & & Early \\
\hline $275.5-285.0$ & 4 & - & - & - & AG & $\mathrm{C}$ & $\mathrm{F}$ & RM & & & Miocene \\
\hline $351.5-361.0$ & 5 & - & - & - & $\mathrm{AG}$ & $\mathrm{C}$ & $\mathrm{F}$ & $\mathrm{RM}$ & & & $-\cdots-1$ \\
\hline $418.0-427.5$ & 6 & - & - & - & CG & $\mathrm{C}$ & $\mathrm{F}$ & $\mathrm{RM}$ & + & & Late \\
\hline $489.5-494.0$ & 7 & RP & RP & - & $\mathrm{CM}$ & $\mathrm{R}$ & $\mathrm{F}$ & RP & + & $\mathrm{F}$ & Oligocene \\
\hline $551.0-560.5$ & 8 & - & - & - & $\mathrm{CP}$ & $\mathrm{R}$ & $\mathrm{R}$ & - & + & $\mathrm{F}$ & --- \\
\hline $589.0-598.5$ & 9 & - & - & - & RP & - & + & - & + & $\mathrm{F}$ & $--\cdots-\cdots$ \\
\hline $636.5-646.0$ & 10 & - & - & - & - & - & - & - & + & $\mathrm{C} / \mathrm{R}$ & Late \\
\hline $703.0-712.5$ & 11 & FP & $\mathrm{CP}$ & $\mathrm{CM}$ & - & - & - & - & - & $\mathrm{R}$ & Middle Eocene \\
\hline $750.5-760.0$ & 12 & FM & $\mathrm{CP}$ & $\mathrm{CM}$ & - & - & - & - & & $\mathrm{R}$ & Middle \\
\hline $779.0-788.5$ & 13 & $\overline{\mathrm{AP}}$ & $\mathrm{CP}$ & $\mathrm{CM}$ & - & - & - & - & & $\mathrm{F}$ & Late Paleocene \\
\hline $788.5-798.0$ & 14 & $\overline{\mathrm{R}} \mathrm{P}$ & RP & $\bar{C} M$ & - & - & - & - & & $\mathrm{C}$ & Early Paleocene \\
\hline $798.0-807.5$ & 15 & - & - & $\mathrm{CP}$ & - & - & - & - & & $\mathrm{R}$ & Middle Maestrichtian \\
\hline $817.0-826.5$ & 16 & $\mathrm{CM}$ & FM & $\mathrm{CP}$ & - & - & - & - & & $\ddot{R}$ & Early Maestrichtian \\
\hline
\end{tabular}

TABLE 7

Distribution, Frequency, and Age of Investigated Fossils at Site 359

\begin{tabular}{|c|c|c|c|c|c|c|c|c|c|}
\hline \multirow{2}{*}{$\begin{array}{l}\text { Site } 359 \\
\text { Depth } \\
\text { (m) }\end{array}$} & \multirow[b]{2}{*}{ Core } & \multicolumn{2}{|c|}{ Foraminifers } & \multirow[b]{2}{*}{$\begin{array}{l}\text { Calcareous } \\
\text { Nannofossils }\end{array}$} & \multirow[b]{2}{*}{ Radiolaria } & \multirow[b]{2}{*}{ Diatoms } & \multirow[b]{2}{*}{$\begin{array}{l}\text { Sponge } \\
\text { Spicules }\end{array}$} & \multirow[b]{2}{*}{$\begin{array}{l}\text { Fish } \\
\text { Debris }\end{array}$} & \multirow[b]{2}{*}{ Age } \\
\hline & & $\begin{array}{l}\text { Plank- } \\
\text { tonic }\end{array}$ & Benthic & & & & & & \\
\hline $0.0-9.0$ & 1 & $\mathrm{AG}$ & AG & $\mathrm{CP}$ & + & + & & & Early Pliocene \\
\hline $28.0-37.5$ & 2 & $\mathrm{CM}$ & $\mathrm{CM}$ & $\mathrm{CM}$ & + & & & & Miocene \\
\hline $56.5-66.0$ & 3 & $\mathrm{AM}$ & $\mathrm{AM}$ & $\mathrm{CM}$ & RP & + & + & & Late Eocene \\
\hline $85.0-94.5$ & 4 & $\mathrm{AM}$ & $\mathrm{AM}$ & $\mathrm{CM}$ & + & + & + & + & \\
\hline $94.5-104.0$ & 5 & \multirow{2}{*}{\multicolumn{2}{|c|}{ (No recovery) }} & & & & & & Volcanic tuff \\
\hline $104.0-107.0$ & 6 & & & & & & & & \\
\hline $9.0-18.5$ & $1 \mathrm{~A}$ & AG & AG & $\mathrm{CM}$ & - & + & & & Late Miocene \\
\hline $18.5-27.0$ & $2 \mathrm{~A}$ & AG & AG & $\mathrm{AM}$ & - & - & & & \\
\hline
\end{tabular}

lowermost sediments above the basement, which was not reached but is assumed to lie about 60 meters below the lowermost core retrieved.

At the other sites, neither oceanic nor continental basement was reached.

\section{Lower Cretaceous}

Lower Cretaceous sediments were recovered only at Site 356 on the São Paulo Plateau. Cores 41 through 44 contain poorly preserved upper Albian assemblages of planktonic foraminifers of the Planomalina buxtorfi and Ticinella breggiensis zones, and calcareous nannofossils of the Eiffellithus turriseiffeli Zone. This zonal correlation is usually found in the upper Albian. Radiolarians in Section 42-6 are common but poorly preserved, and belong to $\mathrm{RK} 4 / \mathrm{RK} 5$, also Lower Cretaceous.

The contact with the Upper Cretaceous sediments is a drilling artifact in Core 41 , and is marked by a lithologic change from hard limestone below to dolomitic calcareous mudstone above. The latter is middle Turonian, so a hiatus spanning the uppermost Albian to the middle Turonian is present at this site.

\section{Upper Cretaceous}

Upper Cretaceous sediments were recovered at Sites 354,355 , and 358 , as discussed above, and at Sites 356 and 357 , as shown in Table 8 and discussed below.

The Cenomanian and lower Turonian are missing at Site 356 on the São Paulo Plateau, where the upper Turonian is also missing and the Campanian was deposited at a relatively slow rate. Turonian through Maestrichtian were zoned by planktonic foraminifers and coccoliths, and the correlation of the two zonations at this site is slightly different from the Maestrichtian correlations suggested by van Hinte (1976) and Thierstein (in press). At Site 357 on the Rio Grande $\mathrm{Rise}$ most of the Campanian and the lower Maestrichtian could not be zoned by planktonic foraminifers, and the correlation of foraminifer and coccolith zones in the rest of the Maestrichtian is the same as at Site 356 , where the first occurrence of Abathomphalus mayaroensis is in the A. cymbiformis Zone, below the first occurrence of $L$. quadratus. This contrasts with Thierstein (in press), who correlates the first occurrence of Micula mura with the first occurrence of $A$. mayaroensis, and with van Hinte 
TABLE 8

Occurrence and Zonation of Cretaceous Sediments at Sites 354 through 358

354

\begin{tabular}{|c|c|c|c|c|}
\hline Age & $\begin{array}{c}\text { Depth } \\
\text { (m) }\end{array}$ & Cores & Foraminifer Zones & Coccolith Zones \\
\hline \multirow{4}{*}{ 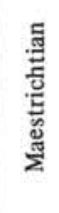 } & \multirow{4}{*}{850} & \multirow{3}{*}{17} & \multirow{4}{*}{ Not zoned } & $N$. frequens \\
\hline & & & & L. quadratus \\
\hline & & & & A. cymbiformis \\
\hline & & 18 & & \\
\hline
\end{tabular}

356

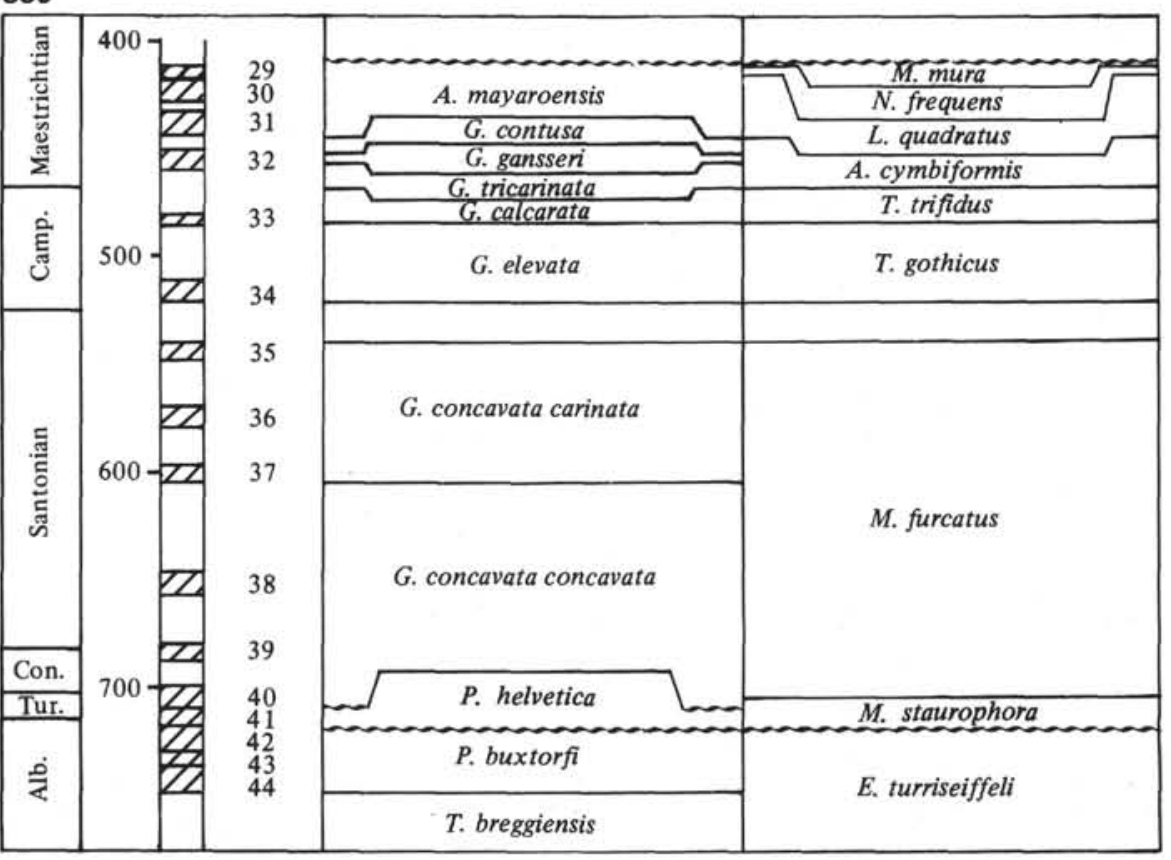

357

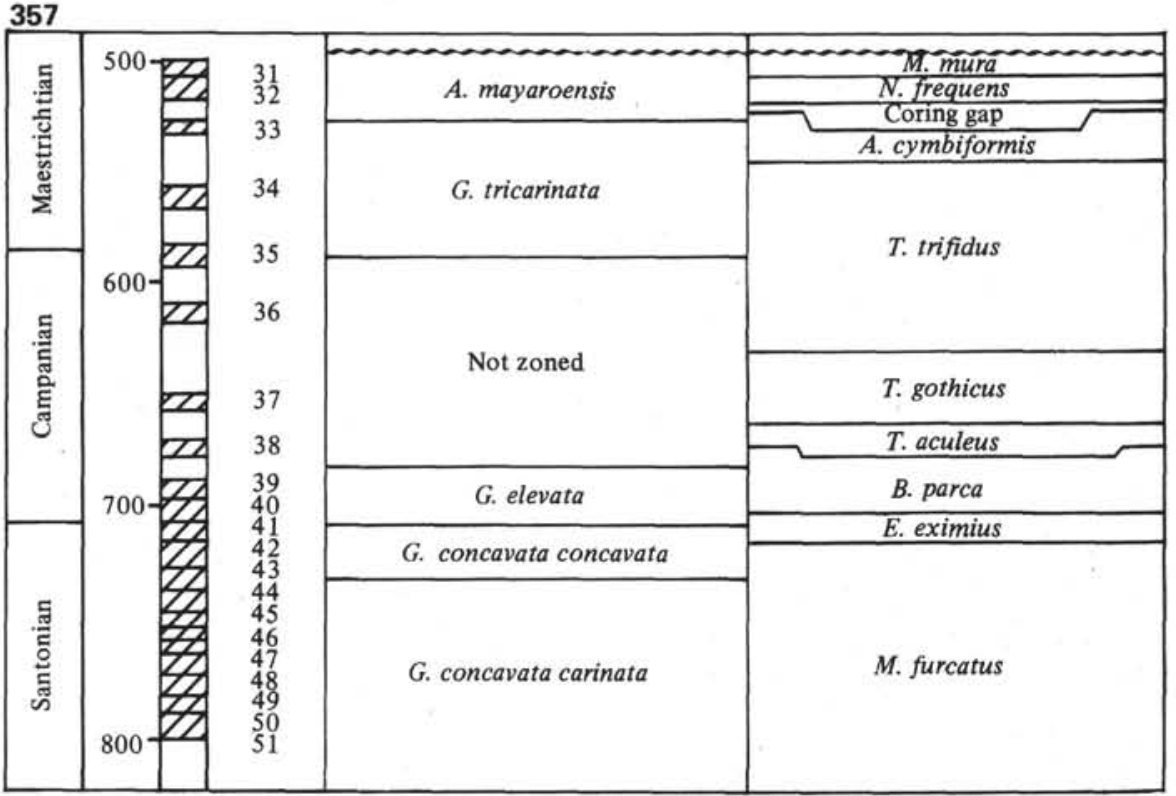




\begin{tabular}{|c|c|c|c|c|}
\hline Age & \begin{tabular}{|c|} 
Depth \\
(m)
\end{tabular} & Cores & Foraminifer Zones & Coccolith Zones \\
\hline 岁 & \multirow{3}{*}{\multicolumn{2}{|c|}{ 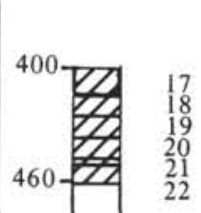 }} & \multirow{3}{*}{ Not zoned } & T. trifidus \\
\hline \multirow{2}{*}{ 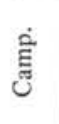 } & & & & $\begin{array}{l}T . \text { gothicus } \\
\text { T. aculeus }\end{array}$ \\
\hline & & & & B. parca \\
\hline
\end{tabular}

\begin{tabular}{|c|c|c|c|c|}
\hline \multirow{2}{*}{ 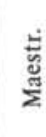 } & \multirow{2}{*}{${ }^{800}$} & \multirow{2}{*}{$\begin{array}{l}15 \\
16\end{array}$} & Not zoned & A. cymbiformis \\
\hline & & & G. tricarinata & T. trifidus \\
\hline
\end{tabular}

(1976), who shows the first occurrence of $M$. mura down in the G. stuarti Zone.

Radiolarians are absent in most Upper Cretaceous samples studied, and no diatoms or other siliceous microfossils were found either. Palynomorphs were studied by Ioannides and Colin (this volume) from the continuously cored Cores 15 through 17 of Site 355 . Core 15 could be dated by radiolarians as early Eocene and most of Core 17 as late Campanian/early Maestrichtian by calcareous nannofossils, but Core 16 contained no fossils. Palynomorphs from the Upper Cretaceous sequence at Site 356 were studied in Cores 38 through 41 . Those in Core 38 furnished an assemblage probably not older than late Coniacian, which correlates well with the early Santonian age indicated for this core by planktonic foraminifers.

\section{Tertiary}

The distribution of Tertiary sediments at Sites 354 through 358 is shown in Tables 9-11 for the Paleogene and in Table 12 for the Neogene. The correlation of the foraminifer, coccolith, and radiolarian zones, as observed during Leg 39 , is generally consistent with that given by Martini (1971) and Berggren (1972). Some minor inconsistencies are discussed below.

\section{Paleogene}

The most interesting and surprising discovery certainly was the quite complete calcareous Danian sequence at Site 356. Danian was also recovered at Sites 357 and 354. Upper Paleocene was recovered from the same sites and from Site 358.

\section{Paleocene}

Site 356 has furnished an excellent opportunity to check the correlation between the coccolith and foraminifer zonations in the Danian. The earliest Tertiary zone of planktonic foraminifers, the $G$. eugubina Zone, correlates with the lowermost part of the lowermost coccolith zone of Markalius inversus, NP 1. The upper part of NP 1 and the whole Cruciplacolithus tenuis Zone, NP 2, is contained in the G. eubulloides Zone, which also includes the lowermost part of the Chiasmolithus danicus Zone, NP 3. This last includes the $G$. triloculinoides Zone (not represented here) and the G. pseudobulloides Zone. The boundary between the $G$. uncinata- $G$. spiralis Zone, P2, and the $G$. pusilla-G. angulata Zone, P3, falls in the Ellipsolithus macellus Zone, NP 4. At Site 358, E. macellus itself was not found, but the occurrence of Chiasmolithus bidens in most samples suggests an equivalent of this, rather than the $C$. danicus Zone, to be present. The absence of $E$. macellus and $E$. distichus is probably not due to their evolutionary absence, but to dissolution-which also has affected the rest of the assemblage-or to the relatively high southern latitude of $38^{\circ} \mathrm{S}$. These species are also missing in high northern latitudes as the stratotype of the Danian, where only two (!) specimens were encountered amongst the millions of coccoliths observed from the uppermost Danian.

The upper Paleocene is less well represented, and a hiatus was found to include most of it at all sites containing any Paleocene at all. The Fasciculithus tympaniformis Zone, NP 5, is represented at Sites 354, 356,357 , and 358 , has its lower boundary within P3, and includes the upper boundary of P3, except at Site 354. Here, only foraminifers of the G. velascoensis Zone, P5, and the G. subbotinae Zone, P 6, were found; the coccoliths indicate a very condensed sequence including NP 5 through the Discoaster multiradiatus Zone, NP 9, in Section 354-16-6.

Radiolarians, present usually in very low numbers and very poor preservation at Site 356 , did not allow zoning. At the other sites, no radiolarians were found in the Paleocene.

\section{Eocene}

No Eocene sequence so far recovered from the western South Atlantic is complete. At Site 354, only the lower middle and the upper upper Eocene were recovered; the correlation between foraminifer and coccolith zones is the same as that suggested by Berggren (1972). At Site 356, the lowermost and the uppermost Eocene are missing, but the rest seems fairly complete. The correlation between foraminifer and coccolith $\mathrm{z}$ nes is different from the one at Site 357, and is also different from those suggested by Martini (1971) and Berggren (1972). The problem involves the 
TABLE 9

Occurrence and Zonation of Paleocene Sediments at Site 354 and at Sites 356 through 358

354

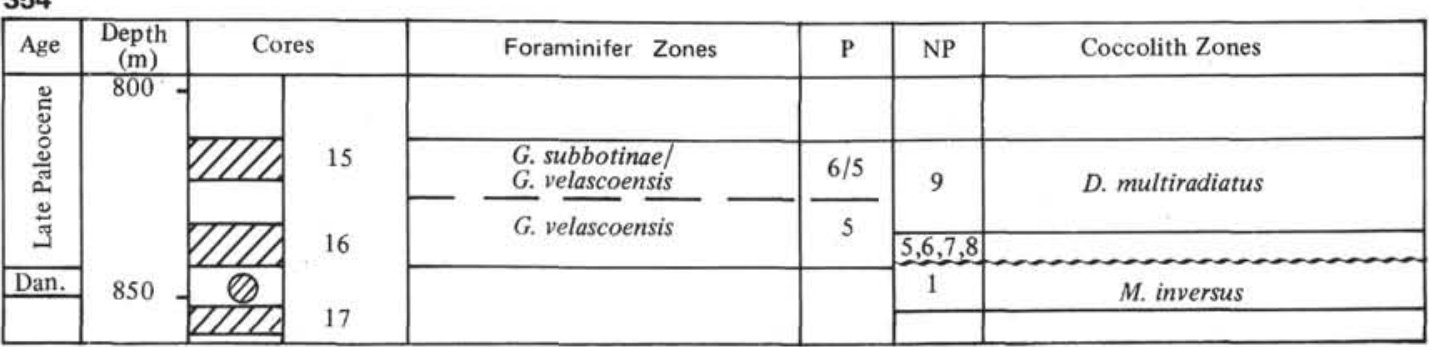

356

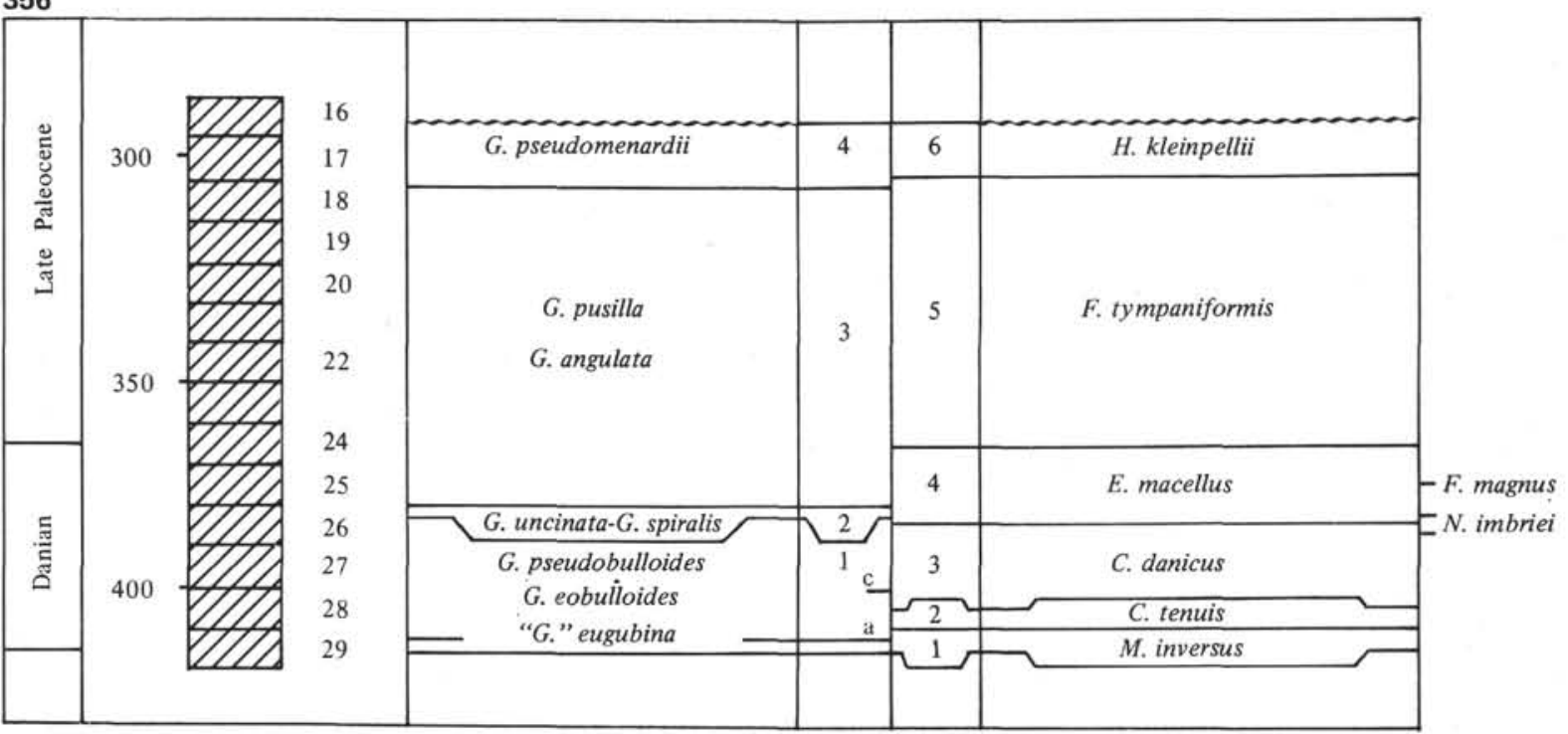

357

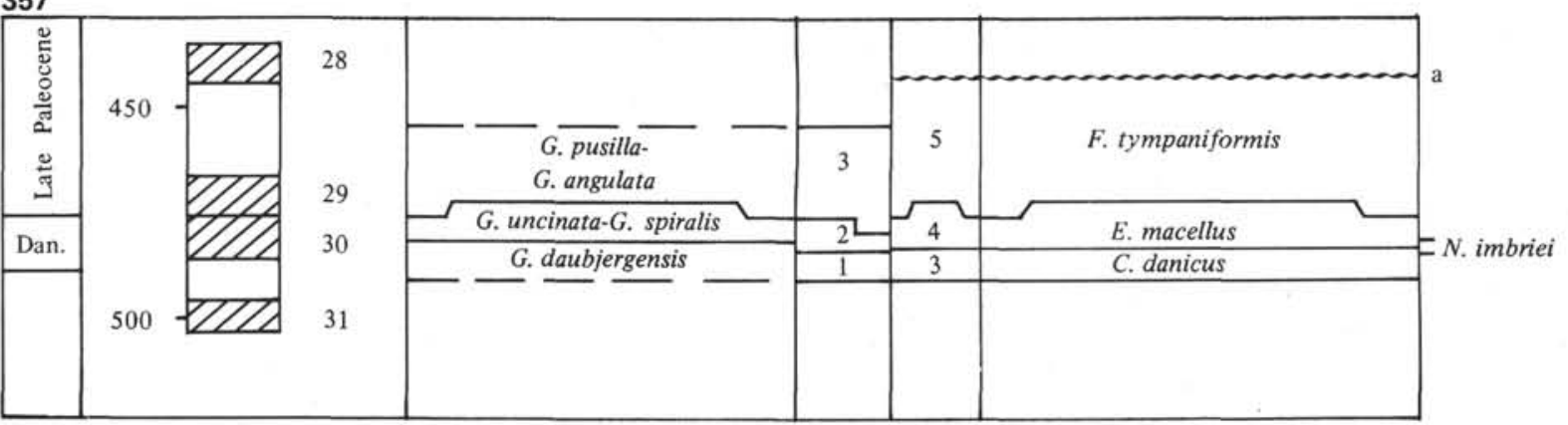

358

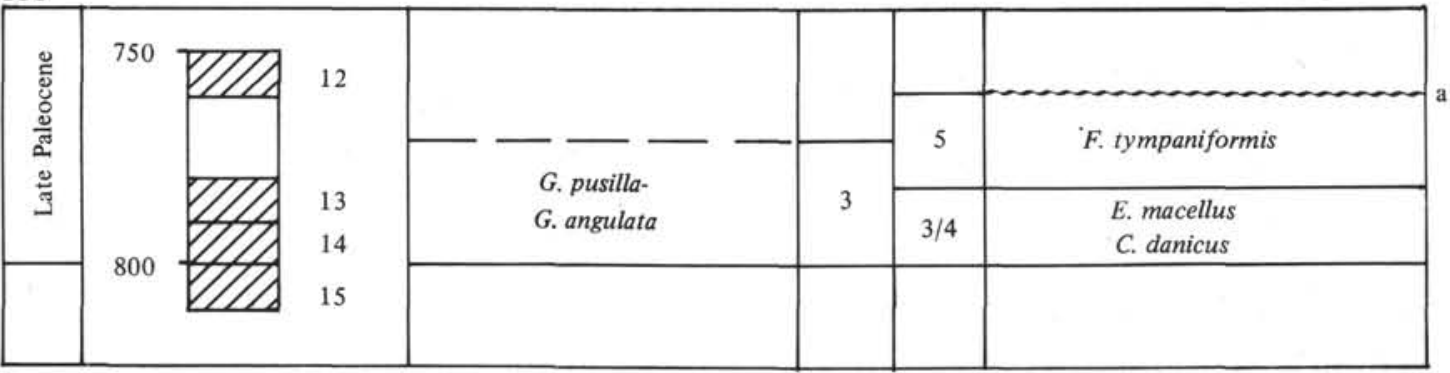

$\mathrm{a}=\mathrm{btm}$. of CC, probably picked up just above Core 29/resp. 13 . 
TABLE 10

흉

Occurrence and Zonation of Eocene Sediments at Sites 354 through 359

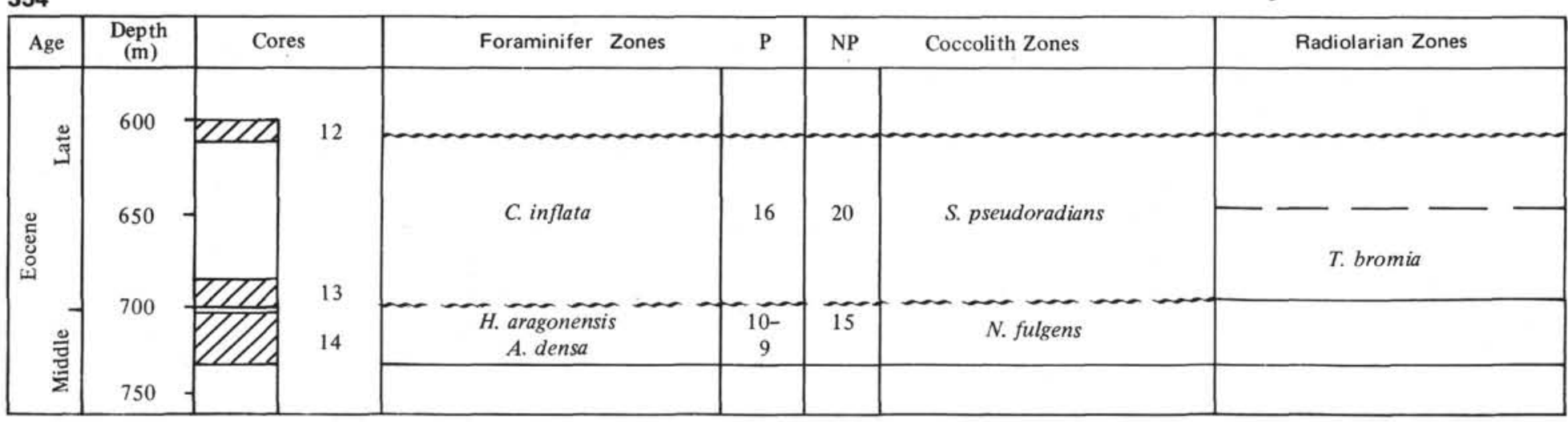

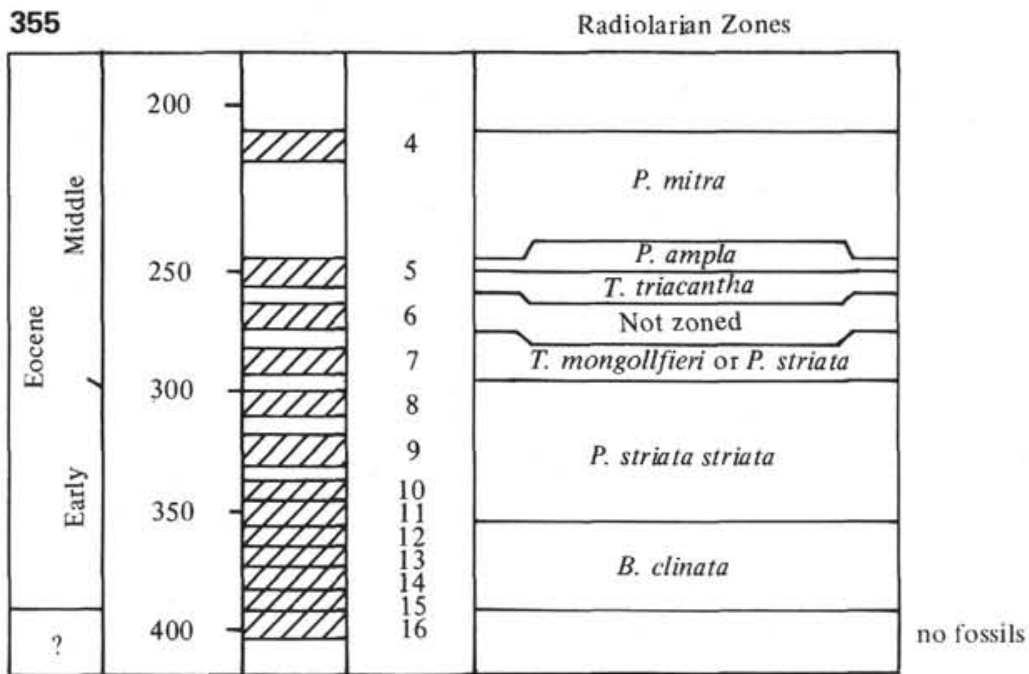

356

Foraminifer Zones

Silicoflagellate Zones

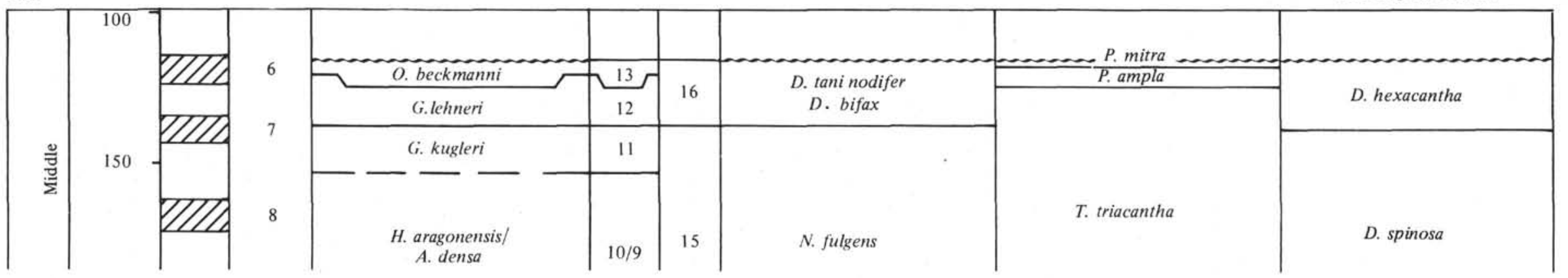



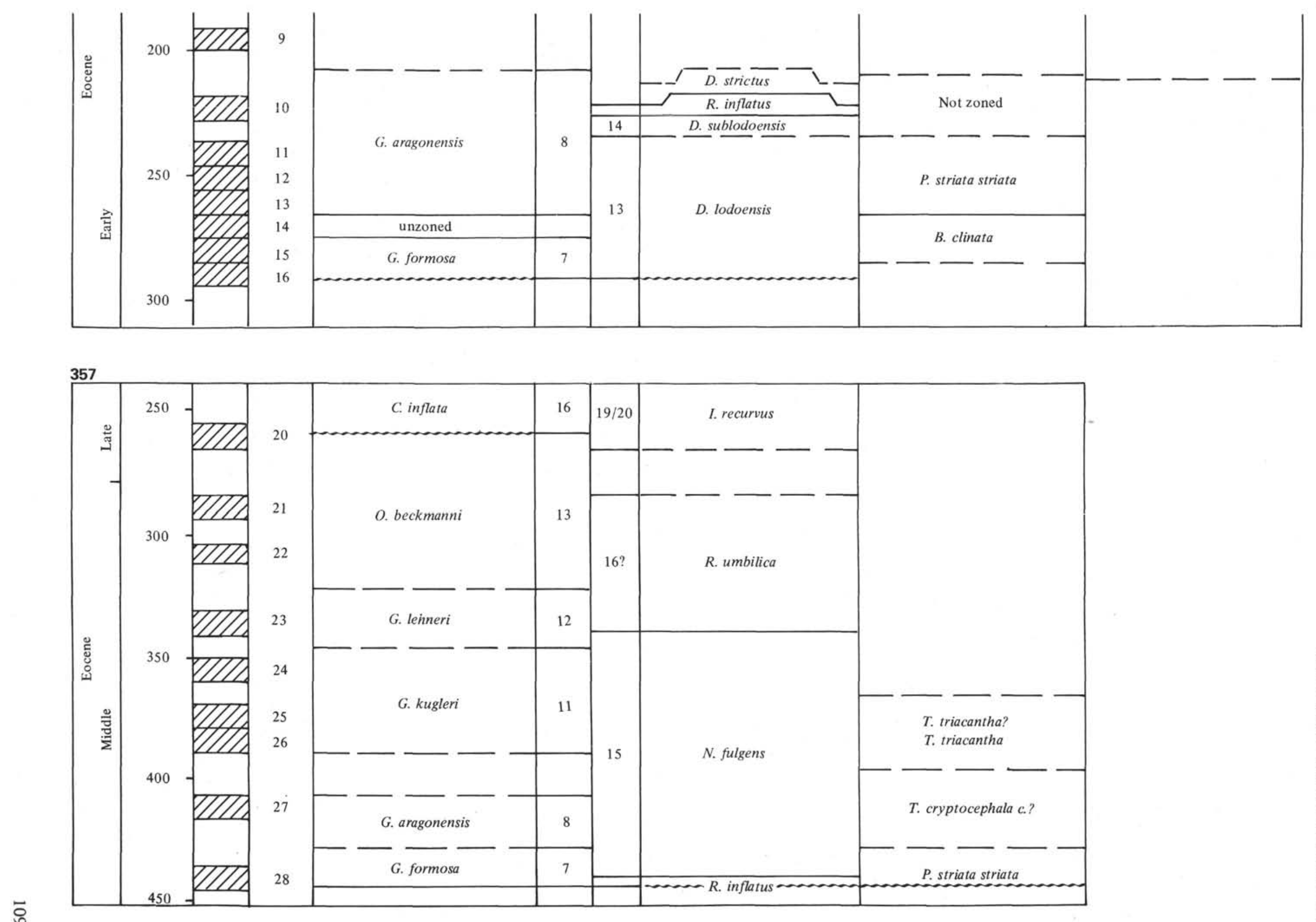
TABLE 10 - Continued

\section{Foraminifer Zones}

Coccolith Zones

\begin{tabular}{|c|c|c|c|c|c|c|}
\hline Age & $\begin{array}{c}\text { Depth } \\
(\mathrm{m})\end{array}$ & \multicolumn{2}{|c|}{ Cores } & \multicolumn{2}{c|}{ Foraminifer Zones } & \multicolumn{2}{c|}{ Coccolith Zones } \\
\hline & 200 & & & & & \\
\hline
\end{tabular}

359

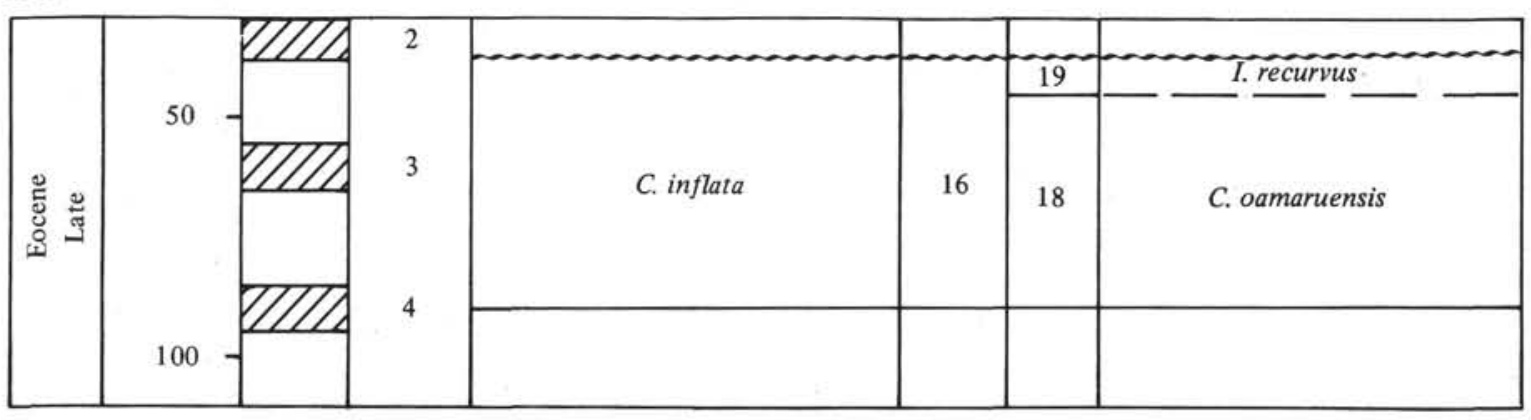


TABLE 11

Occurrence and Zonation of Oligocene Sediments at Sites 354, 357, and 358

354

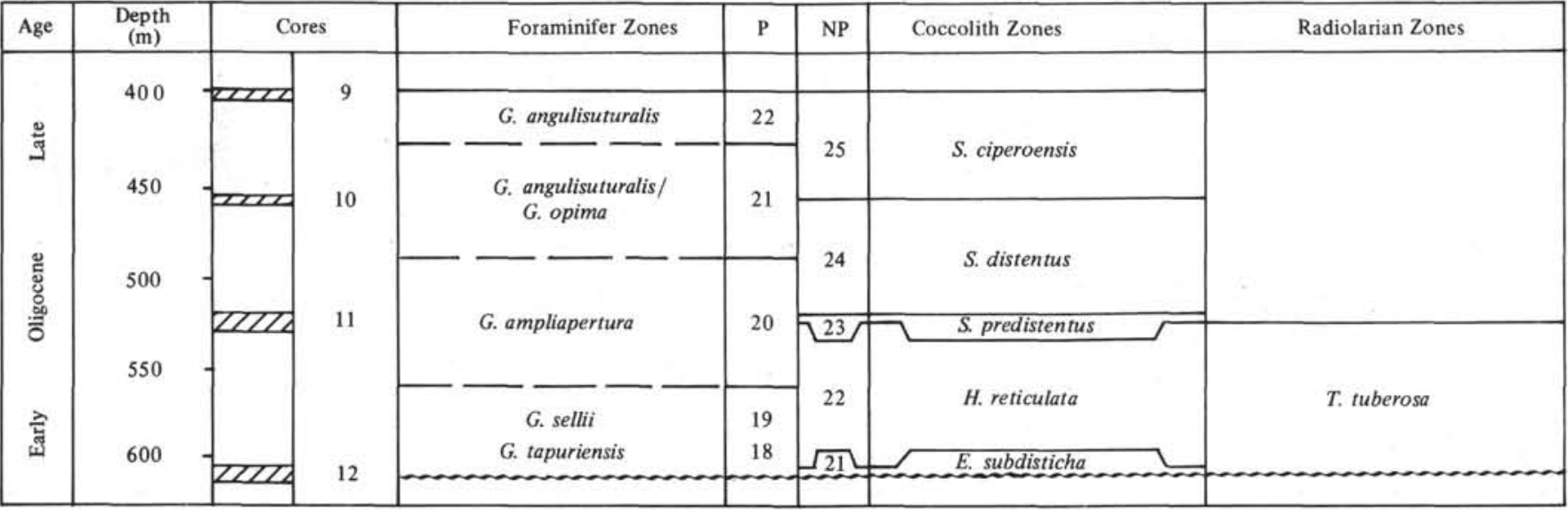

357

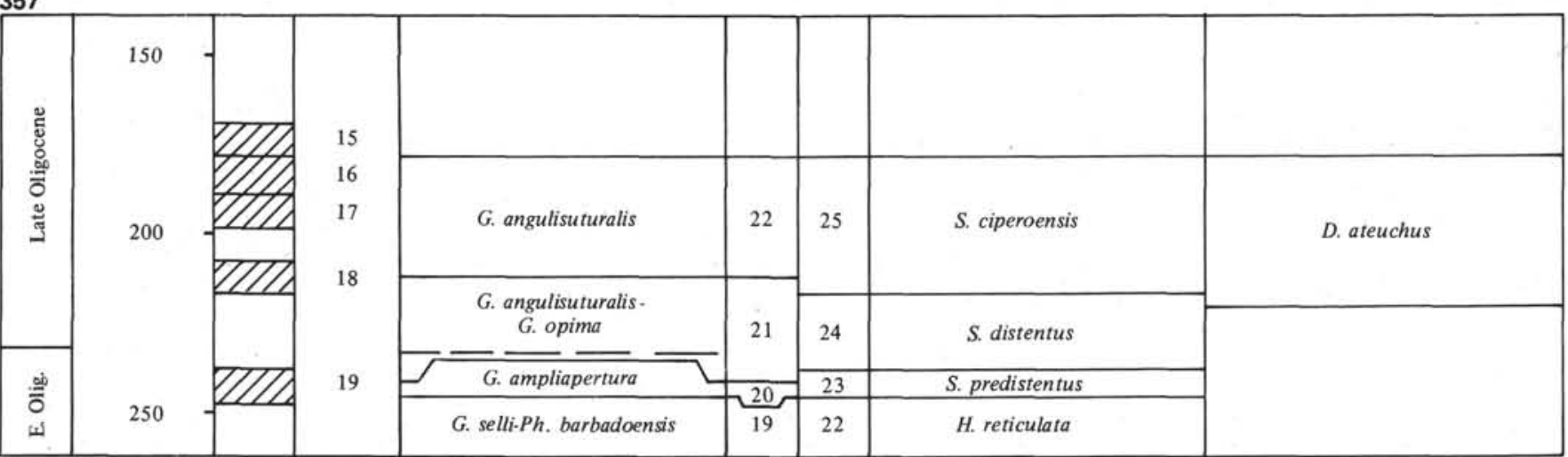

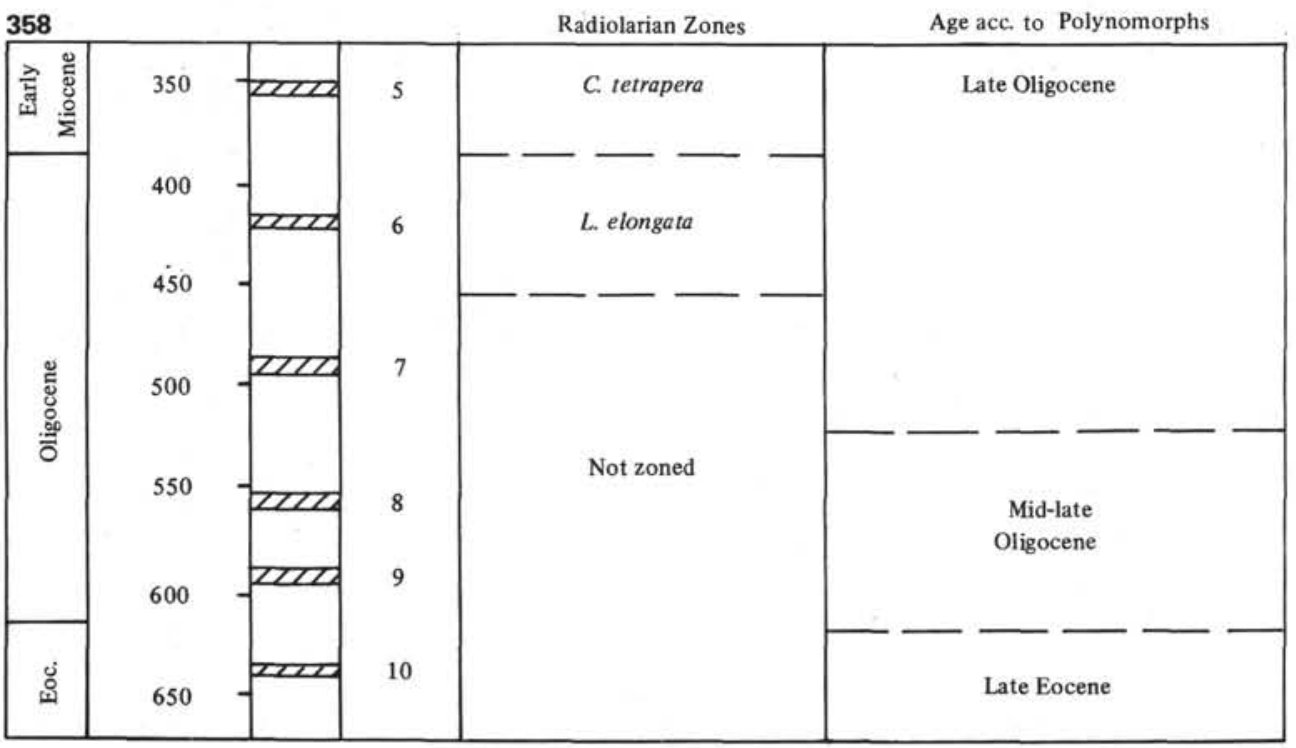


TABLE 12

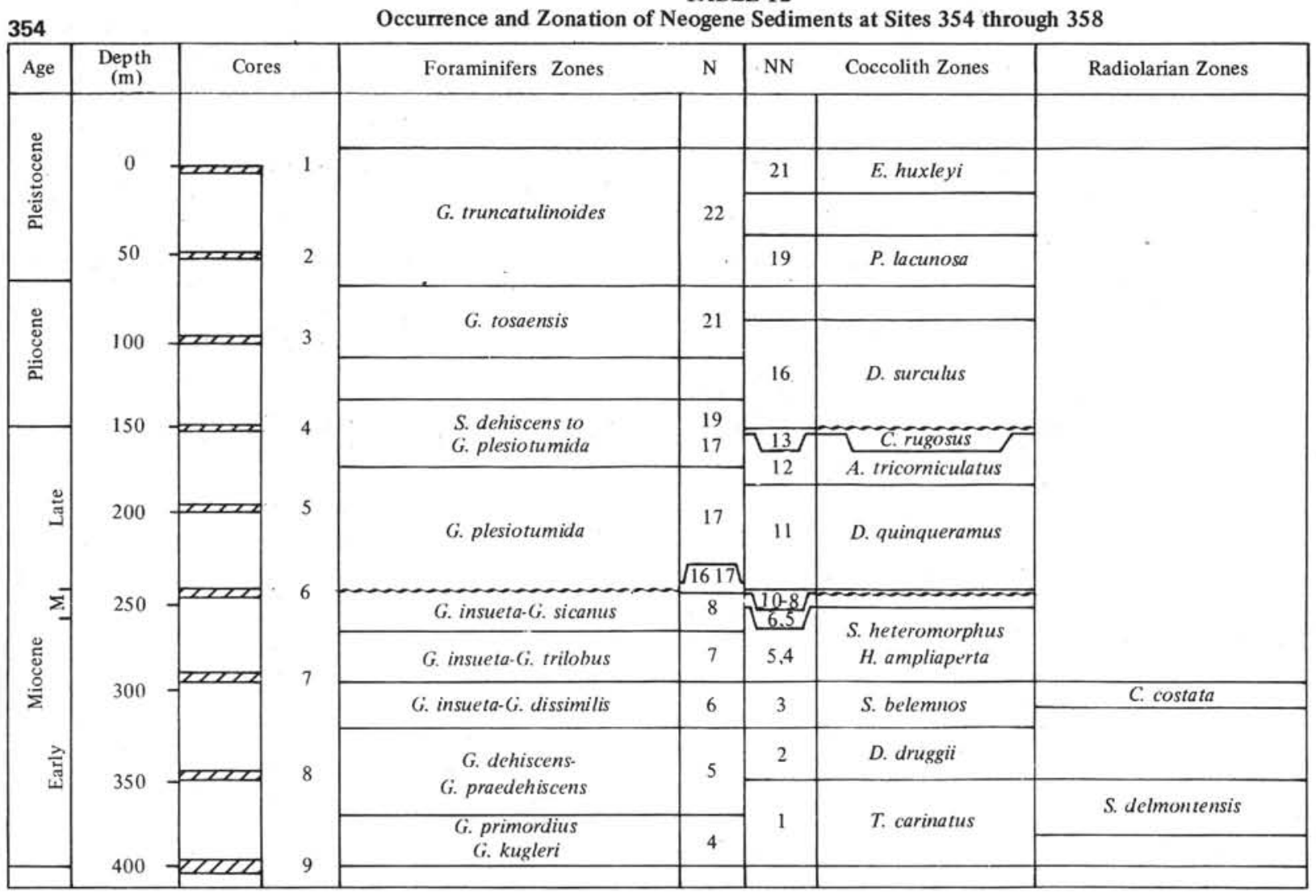

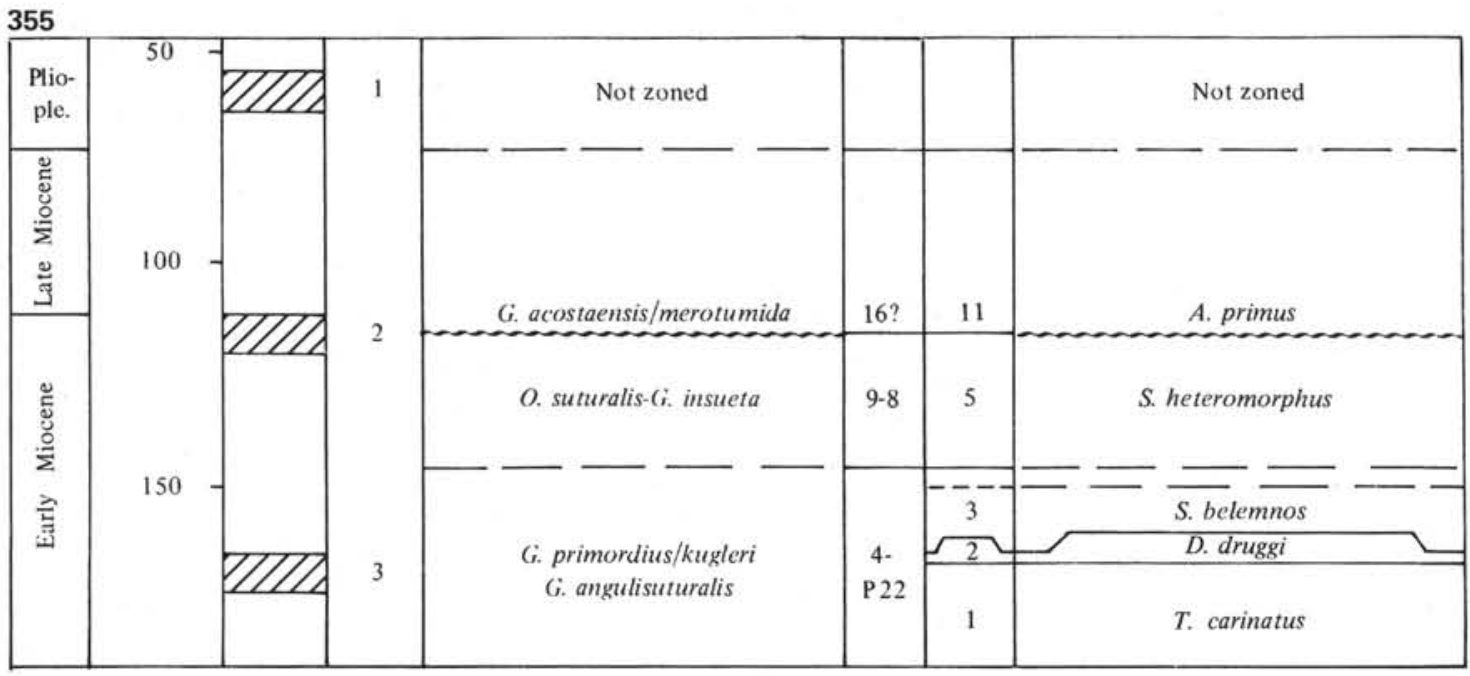



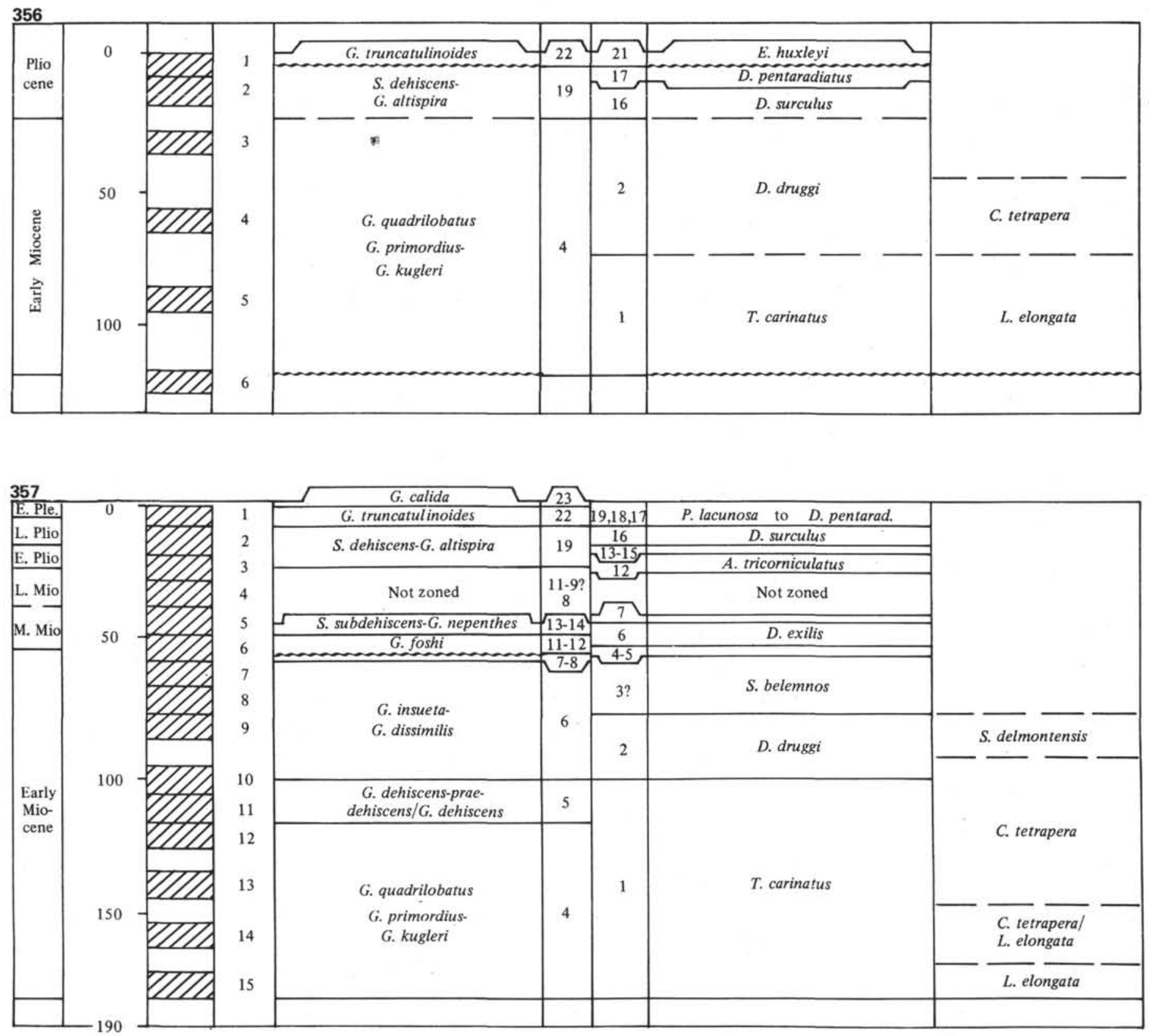
TABLE 12 - Continued

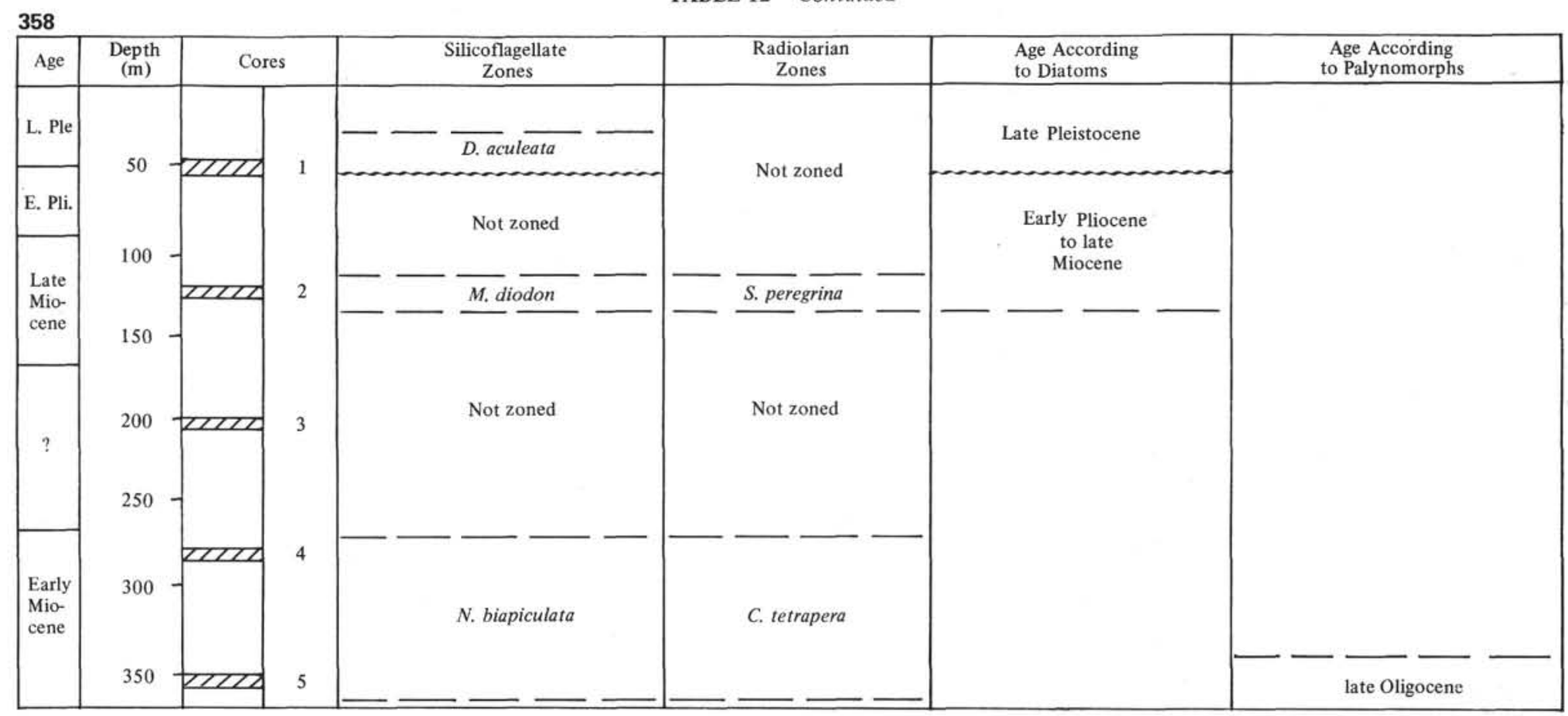


correlation of P8-P10 with NP 13-NP 15 in Cores 8 through 11 of late early Eocene to early middle Eocene age. The discrepancies may arise because the planktonic foraminifers indicate significant cooling between Core 6 and Cores 7 through 10, and because the faunas often were contaminated and lacked zonal indicators.

At Site 357, the lower Eocene is present according to the foraminifers, P 7 in Core 28 , but it is missing according to the coccoliths, NP 14/NP 15 in the same core. At this site, the correlation between the two zonations is different from the ones introduced by Martini (1971) and Berggren (1972) up to the upper middle Eocene, where the top of the Nannotetrina fulgens Zone, NP 15, falls within the G. lehneri Zone, P 12 , as suggested by Berggren (1972). Another inconsistency occurs in Core 20, the uppermost Eocene core. It belongs to the upper Eocene I. recurvus Zone, NP 19. Foraminifers indicate middle Eocene $(O$. beckmanni Zone, P 13) for the lower part of the core, which is disconformably overlain by upper Eocene ( $C$. inflata Zone, P 16).

At Site 358, a late Eocene age was assigned to Core 10 , which contains no calcareous or siliceous microfossils, by the presence of Phthanoperidium eocenicum (see Ioannides and Colin, this volume). The top of Core 11 contains no fossils at all, and the lower part includes mid-Eocene coccolith assemblages, but no planktonic foraminifers allowing zoning. Although only the $G$. formosa Zone, P 7, was reported from Core 12 , this core contains three coccolith zones, NP 13 to NP 11, lower Eocene, a hiatus, and an upper Paleocene assemblage of the Fasciculithus tympaniformis Zone, NP 5.

At Site 355 , the middle and the lower Eocene, as recognized from radiolarians, include Cores 4 to 15 , which are barren of calcareous fossils. Radiolarians are absent in the Eocene at Site 358, but occur in the Eocene of Sites 354, 356, and 359. The upper Eocene at Site 359 also includes Zones P 16, NP 18, and NP 19.

\section{Oligocene}

Calcareous Oligocene sequences were recovered at Site 354 on the Ceará Rise and at Site 357 on the Rio Grande Rise. The Oligocene is missing completely at Sites 355,356 , and 359 . At Site 358 in the Argentine Basin, a noncalcareous, but siliceous sequence of upper Oligocene was dated by radiolarians and silicoflagellates, and a "mid-late Oligocene and Oligocene" interval was dated by palynomorphs (Table 11). It is not possible from our data to make any precise statement as to how much of the Oligocene is represented at this site. It seems, however, that the Oligocene is not complete, that it was deposited at a very slow rate, or that some of it was removed before deposition started again in the late Oligocene.

A fairly complete Oligocene seems to be present at Site 354, where all Oligocene foraminifer and coccolith zones were found. Their correlation follows Berggren's (1972), except for the lower boundary of the Sphenolithus predistentus Zone, NP 23, which is higher-in the G. ampliapertura Zone, P 20-than in Berggren (1972) or Martini (1971), where it occurs in the G. sellii Zone,
P 19. Because of intermittent coring, the Oligocene at this site is not the ideal place to refine the correlation between the two zonations.

At Site 357, the correlation between the foraminifer and coccolith zonations also follows more or less the one found by Berggren (1972). On the other hand, even though the upper part of the Oligocene sequence was cored continuously, the recovery in Cores 15 and 16 was modest, as it was in Cores 18 and 19, where spacing between the cores was 19 meters. All cores were deformed by drilling, and thus are again not ideal for studying biostratigraphic correlation.

\section{Neogene}

Neogene sequences were recovered at all sites drilled on Leg 39 (Table 12). Generally, the Neogene was only spot-cored, so the biostratigraphic results from all these sites are patchy at best. Only at Site 357 was a special effort made to collect as complete a Neogene section as possible.

At Site 353 in the Vema Fracture Zone, only Pleistocene turbidites were recovered. A fairly complete calcareous Noegene sequence was found at Site 354, where the correlation of planktonic foraminifer and coccolith zones follows Berggren (1972) reasonably well. The mid Miocene hiatus, however, seems more extensive according to the foraminifers than according to the coccoliths. This is because the accumulation rate during the whole middle Miocene and the early late Miocene was extremely low. The whole middle Miocene and lower upper Miocene are contained in the $60 \mathrm{~cm}$ at the bottom of Section 354-6-3, from which coccolith samples were taken at $1-\mathrm{cm}$ intervals; only two samples above and below the condensed sequence for foraminifer zonation were studied. An apparent hiatus between NN 13 and NN 16 in the slightly disturbed Core 4 was not found by foraminifers, but might be a result of coring disturbance.

Surprisingly, two of the three Neogene cores collected at Site 355 in the Brazil Basin (water depth $4896 \mathrm{~m}$ ) could be dated by foraminifers and coccoliths; Core 2 even contains a hiatus between the upper and lower Miocene, and the entire middle Miocene is missing. Correlation of the two zonal systems is as proposed by Berggren (1972). At the other basinal site, Site 358 in the Argentine Basin (water depth $5000 \mathrm{~m}$ ), the whole Neogene lacks calcareous microfossils and was zoned using radiolarians and silicoflagellates. Fenner (this volume) found a hiatus in Core 1, and observed upper Pleistocene diatoms above and lower Pliocene to upper Miocene diatom assemblages below in the disturbed core. Thus, the hiatus may be a drilling artifact. Core 5 , assigned to the lower Miocene $C$. tetrapera Zone by radiolarians, is assigned a of late Oligocene age, by palynomorphs (Ioannides and Colin, this volume).

At the two sites on topographic highs, 356 and 357, relatively thick sequences of lower Miocene sediments were recovered. Of 115 meters of Neogene sediments at Site 356, 90 meters are lower Miocene. At Site 357, 130 meters of 180 meters of Neogene sediments belong to the lower Miocene. Correlation of foraminifer and coccolith zones in the incomplete Neogene sequence at 
Site 356 more or less follow Berggren (1972); no new observations were possible about the sequence of zonal boundaries, since zonal boundaries fall between the few cores. At Site 357, all Neogene cores have been disturbed by drilling, but recovery was relatively high in this almost continuously cored Neogene sequence. Correlation of coccolith and foraminifer zones in the lower Miocene of Cores 15 through 7 follows closely those suggested by Berggren. Problems occur with Core 6 , which contains a hiatus spanning from $\mathrm{N} 7-\mathrm{N} 8$ to $\mathrm{N}$ $11-\mathrm{N} 12$, but in which all corresponding coccolith zones, although condensed, are represented (NN 3, 4-5, $6)$. In Core 5 , correlation is off by one zone; the foraminifers indicate younger assemblages than the coccoliths. The uppermost part of this core and Core 4 could not be zoned satisfactorily, but were assigned a late Miocene age by Berggren (this volume). Also, the lower part of Core 3 could not be zoned, but the upper part of Core 3 belongs to the Amaurolithus tricorniculatus Zone, NN 12, which spans the Miocene/Pliocene boundary and the $S$. dehiscens- $G$. altispira Zone, $\mathrm{N} 19$, which also extends through Core 2. N 19 here correlates with NN 13-15 and NN 16, of early Pliocene age. Disagreement occurs between the foraminifers, indicating a Pleistocene age (N 22) for Core 1 , and the coccoliths, indicating a late Pliocene age (NN 16-NN 18). Upper Pleistocene was found only in a water core that must have touched bottom and yielded an upper Pleistocene (N 23) foraminifer assemblage.
Thirty-seven meters of Neogene were encountered at Site 359. These middle and upper Miocene and lower Pliocene sediments could only be zoned properly by foraminifers.

\section{REFERENCES}

Berggren, W.A., 1972. A Cenozoic time-scale-some implications for regional geology and paleobiogeography: Lethaia, v. 5, p. 195-215.

Bukry, D., Dinkelman, M.G., and Kaneps, A., 1973. Biostratigraphy of the Equatorial East Pacific Rise. In van Andel, T.H., Heath, G.R., et al., Initial Reports of the Deep Sea Drilling Project, Volume 16: Washington (U.S. Government Printing Office), p. 915-935.

Martini, E., 1971. Standard Tertiary and Quaternary calcareous nannoplankton zonation. In Farinacci, A. (Ed.), Plankt. Conf. Second. Roma 1970. Proc.: Roma (Tecnoscienza), v. 2, p. 739-785.

Maxwell, A.E. et al., 1970. Initial Reports of the Deep Sea Drilling Project, Volume 3: Washington (U.S. Government Printing Office)

Thierstein, H., in press. Biostratigraphy of marine Mesozoic sediments by calcareous nannoplankton. 3rd Planktonic Conf. Proc. (See Fig. 12 in Berger, W.H. and Roth, P.H., 1975. Oceanic Micropaleontology: Progress and Prospect. Reviews of Geophysics and Space Physics, v. 13, p. 561635.)

Van Hinte, J.E., 1976. A Cretaceous time scale: Am. Assoc. Petrol. Geol. Bull., v. 60, p. 498-516. 